\title{
PENILAIAN AUTENTIK PADA PEMBELAJARAN BERBASIS TEMATIK DALAM MENINGKATKAN KUALITAS PROSES PEMBELAJARAN BAGI GURU MADRASAH IBTIDAIYAH DI WATAMPONE
}

\section{AUTHENTIC ASSESMENT OF THEMATIC-BASED LEARNING IN IMPROVING THE QUALITY OF LEARNING PROCESSES FOR ISLAMIC ELEMENTARY SCHOOL TEACHERS IN WATAMPONE}

\author{
Samsinar $S$. \\ Pascasarjana Program Studi Pendidikan Agama Islam IAIN Bone \\ Jl. HOS. Cokroaminoto Watampone \\ Email : Samsinars77@yahoo.com
}

Naskah diterima tanggal 8 Maret 2019, Naskah direvisi tanggal 27 April 2019, Naskah disetujui tanggal 30 Mei 2019

\begin{abstract}
Abstrak
Penelitian ini bertujuan mengklasifikasikan bentuk penerapan penilaian autentik pada pembelajaran berbasis tematik, kualitas proses pembelajaran, serta faktor pendukung dan penghambat guru Madrasah Ibtidaiah di Watampone dalam menerapkan penilaian autentik pada pembelajaran berbasis tematik untuk meningkatkan kualitas proses pembelajaran. Metode penelitian deskriptif kualitatif dengan menggunakan wawancara, observasi dan dokumentasi. Hasil penelitian menunjukkan bahwa ada tiga bentuk penilaian autentik yang diterapkan oleh guru yaitu penilaian kompetensi sikap, penilaian kompetensi pengetahuan, penilaian kompetensi keterampilan. Selanjutnya, guru Madrasah Ibtidaiah di Watampone meningkatkan kualitas proses pembelajaran dengan cara melakukan perencanaan, pelaksanaan, penilaian dan pengawasan dalam proses pembelajaran. Dalam menerapkan penilaian autentik ini ada beberapa faktor yang menjadi pendukung dan penghambat. Faktor-faktor yang menjadi pendukung adalah guru diberi kesempatan untuk meningkatkan kompetensi khususnya dalam melakukan penilaian pembelajaran melalui pelatihan penilaian autentik, buku panduan penilaian, pendampingan baik dari kepala sekolah, pengawas, kelompok kerja guru, dan teman sejawat dalam mendesain penilaian autentik. Selain faktor pendukung, ada juga beberapa hal yang menjadi penghambat dalam menerapkan penilaian autentik yaitu kemampuan guru Madrasah Ibtidaiah di Watampone yang berbeda-beda, terbatasnya waktu, ribet dan tidak praktis. Implikasi dalam penelitian ini, penilaian autentik merupakan hal yang urgen yang harus diterapkan dan dikembangkan oleh guru Madrasah Ibtidaiah di Watampone, agar tidak hanya menilai kompetensi pengetahuan dan keterampilan peserta didik, akan tetapi menilai kompetensi sikap peserta didik baik di kelas maupun di luar kelas. Oleh karena itu, diperlukan kemauan, kesadaran, dan keterampilan guru dalam menerapkan dan mengembangkan penilaian ini agar terhindar dari unsur subjektivitas sehingga kualitas proses dalam pembelajaran meningkat.
\end{abstract}

Kata kunci : penilaian autentik, kualitas, proses pembelajaran

\begin{abstract}
This study aims to classify the form of the application of authentic assessments on thematic-based learning, the quality of the learning process, and the supporting and inhibiting factors of Islamic Madrasah teachers in Watampone in applying authentic assessment of thematic-based learning to improve the quality of the learning process. Qualitative descriptive research method using interviews, observation and documentation. The results showed that there were three forms of authentic assessment applied by the teacher, namely attitude competency assessment, knowledge competency assessment, skills competency assessment. Furthermore, Madrasah Ibtidaiah teachers in Watampone improve the quality of the learning process by doing planning, implementation, assessment and supervision in the learning process. In applying this authentic assessment there are several factors that are supporting and inhibiting. The supporting factors are that the teacher is given the opportunity to improve competence, especially in
\end{abstract}


conducting learning assessments through authentic assessment training, assessment guide book, mentoring from principals, supervisors, teacher working groups, and peers in designing authentic assessments. In addition to supporting factors, there are also some things that become obstacles in applying authentic assessment, namely the ability of Islamic Elementary School teachers in Watampone that are different, limited in time, complicated and impractical. Implications in this study, authentic assessment is an urgent matter that must be applied and developed by Islamic Elementary School teachers in Watampone, so as not only to assess the competencies of knowledge and skills of students, but to assess the competencies of attitudes or behavior of students both in class and outside class. Therefore, the teacher's willingness, awareness and skills are needed in implementing and developing this assessment so that it acts from the element of subjectivity, so that the quality of the process in learning increases.

Keywords: authentic assessment, the quality, learning process

\section{PENDAHULUAN}

$\mathrm{P}$ enilaian atau evaluasi pembelajaran merupakan bagian yang tak terpisahkan dari proses pembelajaran dan dapat menentukan kualitas dari suatu kegiatan pembelajaran. Terkait dengan implementasi kurikulum, evaluasi merupakan bagian penting dari perangkat kurikulum yang dilakukan untuk mengukur dan menilai tingkat kompetensi. Evaluasi harus digunakan untuk mengetahui kekuatan dan kelemahan dalam proses pembelajaran, serta untuk melakukan diagnosis dan perbaikan pembelajaran. Sebuah proses pembelajaran yang bermakna memerlukan sistem penilaian yang baik, terencana dan berkesinambungan. (Sani, 2016:1) Dengan demikian, guru harus memiliki pengetahuan yang baik tentang evaluasi pembelajaran terutama penilaian autentik. Melalui kurikulum 2013 ini penilaian autentik menjadi penekanan yang serius bagi guru dalam melakukan penilaian proses dan hasil belajar peserta didik (Kunandar, 2014:35).

Menurut Supardi (2016:26) karakteristik penilaian autentik ini berasal dari aspek kondisi peserta didik, dimulai dengan guru menilai input yaitu kondisi awal peserta didik, proses yaitu kinerja dan aktivitas peserta didik dalam proses pembelajaran, dan output yaitu hasil pencapaian kompetensi, baik sikap, pengetahuan dan keterampilan yang dikuasai dan ditampilkan oleh peserta didik setelah mengikuti proses pembelajaran.

Penilaian ini menggunakan berbagai cara dan kriteria holistis yakni kompetensi secara utuh yang merefleksikan pengetahuan, keterampilan dan sikap. (Sani, 2016:74) Oleh karena itu, penilaian tidak hanya dilihat dari satu aspek saja yaitu pengetahuan, akan tetapi keterampilan dan sikap juga menjadi aspek penilaian.

Pada kenyataannya, permasalahan yang dihadapi oleh guru madrasah di Watampone adalah sulitnya mengubah paradigma guru tentang penilaian yang seharusnya dilakukan. Pada umumnya, guru madrasah di Watampone hanya mengenal instrumen penilaian berupa tes dan menganggap bahwa penilaian hanya perlu dilakukan setelah peserta didik menyelesaikan proses belajar, terbiasa menggunakan penilaian secara kuantitatif sehingga penilaian secara kualitatif yang mencakup informasi tentang kelemahan dan keunggulan peserta didik sulit untuk dilakukan. Selain itu, guru hanya menggunakan instrumen lembar observasi dalam menilai sikap peserta didik. Dengan kesulitan ini maka solusi yang terpenting adalah guru harus memahami tentang penilaian autentik untuk menilai penguasaan peserta didik tidak hanya pada aspek kognitif atau pengetahuannya saja tetapi keterampilan dan sikap juga dinilai sesuai tuntutan kompetensi dari masing-masing pembelajaran. Hadirnya kurikulum 2013, menuntut guru untuk memahami dan menggunakan penilaian autentik pada pembelajaran berbasis tematik.

Dengan adanya tuntutan inilah guru harus lebih kreatif, profesional dan inovatif dalam mengembangkan dan menerapkan penilaian autentik dalam pembelajaran sehingga dapat meningkatkan kualitas penilaian proses 
pembelajaran yang berakibat pada peningkatan kualitas atau mutu pendidikan. Dengan demikian, jika menginginkan pembelajaran berkualitas maka kunci utamanya terletak pada guru. Gurulah yang harus memainkan peran aktif agar dapat membelajarkan peserta didik dengan baik dan dapat mencapai tujuan dalam pembelajaran.

Selain itu, kualitas proses pembelajaran dapat dilihat pada standar proses yang tertuang dalam Peraturan Menteri Pendidikan dan Kebudayaan Republik Indonesia Nomor 65 tahun 2013 yaitu perencanaan, pelaksanaan, penilaian, hasil dan pengawasan dalam proses pembelajaran. Dengan guru memperhatikan dan melaksanakan keempat aspek ini maka akan meningkatkan pembelajaran yang berkualitas sehingga menghasilkan luaran yang berkualitas juga. Oleh karena itu, keempat aspek ini menjadi kunci dalam keberhasilan proses pembelajaran. Jika guru merencanakan pembelajaran dengan baik melalui desain yang baik, melaksanakan pembelajaran melalui penggunaan model, metode, media, sumber belajar sesuai dengan karakteristik peserta didik dan mata pelajaran, serta mampu mengelola kelas dengan baik, melakukan penilaian yang mengacu pada penilaian autentik yaitu mengevaluasi kemampuan peserta didik dalam konteks dunia nyata, dalam hal ini peserta didik belajar dengan mengaplikasikan pengetahuan dan keterampilannya melalui tugas-tugas autentik.

Melalui kelas autentik berbasis penilaian, guru dan peserta didik dapat melihat pembelajaran riil dan perkembangan yang terjadi. Oleh karena itu, penilaian yang baik adalah penilaian autentik dan penilaian autentik akan meningkatkan pembelajaran dan dengan pembelajaran yang baik akan meningkatkan kualitas dan prestasi peserta didik (Pantiwati:2018).

Selain itu, kualitas proses pembelajaran juga mengacu pada aspek pengawasan dalam pembelajaran. Pengawasan dilakukan dengan cara pemantauan, supervisi, pelaporan dan tindak lanjut. Dengan demikian, guru Madrasah Ibtidaiah di Watampone harus memaksimalkan keempat aspek di atas dalam proses pembelajaran agar dapat meningkatkan kualitas pembelajaran.

\section{Tinjauan Pustaka}

\section{Penilaian Autentik dalam Pembelajaran Tematik Pada Kurikulum 2013}

Penilaian pembelajaran merupakan salah satu kegiatan dalam pembelajaran. Kegiatan ini harus dilakukan untuk mengetahui hal-hal penting baik yang berupa kelebihan maupun kekurangan yang terjadi pada kegiatan pembelajaran yang telah berlangsung. Guru sebagai evaluator harus mengetahui kekurangankekurangan yang ada dalam pembelajaran agar dapat melakukan perbaikan pada pembelajaran berikutnya. Begitu juga dia harus mengetahui kelebihan-kelebihan yang ada dalam pembelajaran agar dia dapat mempertahankan dan mengembangkan kelebihan tersebut.

The Task Group on Assessment and Testing (TGAT) dalam S. Eko Putro Widoyoko (2017:2-3) mengemukakan bahwa penilaian atau asesmen sebagai semua cara yang digunakan untuk menilai unjuk kerja individual atau kelompok. Penilaian juga diartikan sebagai kegiatan menafsirkan data hasil pengukuran berdasarkan kriteria maupun aturan-aturan tertentu. Selain itu, penilaian merupakan suatu kegiatan untuk memberikan berbagai informasi secara berkesinambungan dan menyeluruh tentang proses dan hasil yang telah dicapai oleh peserta didik. Kegiatan menyeluruh dimaksudkan untuk menunjukkan bahwa penilaian tidak hanya melibatkan aspek kognitif, tetapi juga aspek afektif dan psikomotorik (Arifin, 2016:10-11).

Salah satu penilaian yang sangat penting dilakukan oleh guru adalah penilaian autentik. Penilaian ini diterapkan sesuai dengan kurikulum yang berlaku pada saat sekarang ini yaitu kurikulum 2013. Salah satu penekanan dalam kurikulum 2013 adalah penilaian autentik. Pada kurikulum sebelumnya, Kurikulum Tingkat Satuan Pendidikan (KTSP) sudah memberi ruang terhadap penilaian autentik, akan tetapi dalam implementasinya di lapangan belum berjalan secara optimal. Melalui kurikulum 2013 ini penilaian autentik menjadi penekanan yang serius bagi guru dalam melakukan penilaian proses dan hasil belajar peserta didik (Kunandar, 2014:35). 
Istilah penilaian autentik diperkenalkan oleh Wiggins pada tahun 1990. Wiggins menentang penilaian yang bersifat umum yang dilakukan di sekolah, seperti isian singkat, tes pilihan ganda, dan tes sejenis. Menurutnya, orang diuji dengan cara menunjukkan kemampuannya secara langsung atau dengan menunjukkan produk yang telah dibuatnya. Sebagai contoh, orang akan mempekerjakan seorang sopir yang dapat mengisi tes tentang menyetir, daripada memilih seorang sopir yang dapat mengisi tes tentang menyetir namun tidak mampu menyetir. Penilaian yang tepat untuk menguji sopir adalah dengan uji praktik menyetir dengan menggunakan kendaraan di jalan raya. Penilaian seperti ini sesuai dengan kompetensi yang diuji dan disebut sebagai penilaian autentik (Sani, 2016:22). Dengan demikian penilaian autentik yaitu menilai kompetensi peserta didik yang didasarkan pada kompetensi sikap, keterampilan dan pengetahuannya dalam kehidupan sehari-hari.

Penilaian autentik pada kurikulum 2013 SD/MI dilihat dari segi kompetensi yang dinilai dapat diklasifikasikan menjadi tiga yaitu penilaian kompetensi sikap dengan menggunakan teknik observasi, penilaian diri, penilaian teman sejawat oleh peserta didik, dan jurnal; penilaian kompetensi pengetahuan dengan menggunakan tes tertulis, tes lisan, dan penugasan; penilaian kompetensi keterampilan dengan menggunakan penilaian kinerja berupa tes praktik, proyek, dan penilaian portofolio (Permendikbud RI No. 66 Tahun 2013). Untuk dapat melaksanakan penilaian autentik, guru harus memenuhi kriteria tertentu yaitu mengetahui cara menilai kekuatan dan kelemahan peserta didik serta desain pembelajaran, mengetahui cara membimbing peserta didik untuk mengembangkan pengetahuan mereka sebelumnya dengan cara mengajukan pertanyaan dan menyediakan sumber daya memadai bagi peserta didik untuk melakukan akuisisi pengetahuan, menjadi pengasuh proses pembelajaran, melihat informasi baru, dan mengasimilasikan pemahaman peserta didik, dan menjadi kreatif untuk mengembangkan proses belajar peserta didik dengan mencari pengetahuan dari luar sekolah (Daryanto dan Syaiful Karim, 2017:17).
Penilaian autentik akan berhasil dengan baik jika para guru memiliki kompetensi dalam mendesain pembelajaran, memahami karakteristik peserta didik, memanfaatkan sumber belajar dalam pembelajaran, dan meningkatkan serta mengembangkan kompetensi pengetahuannya baik di sekolah dan di luar sekolah.

\section{Kualitas Proses dalam Pembelajaran di Madrasah}

Kualitas atau mutu memiliki pengertian yang beragam dan memiliki implikasi yang berbeda jika diterapkan pada sesuatu tergantung pada apa yang dihasilkan, digunakan, dan anggapan orang. Menurut Gaspersz sebagaimana yang dikutip dalam Nurzazin (2011:54) bahwa mutu memiliki definisi yang berbeda dan bervariasi, dari konvensional sampai modern. Definisi konvensional mendefinisikan karakteristik langsung dari suatu produk, sedangkan definisi modern menjelaskan bahwa mutu adalah segala sesuatu yang mampu memenuhi keinginan atau kebutuhan pelanggan.

Kualitas atau mutu dapat juga diartikan sebagai kesesuaian penggunaan atau tepat untuk dipakai. Pendekatannya adalah orientasi pada pemenuhan kebutuhan pengguna, dengan beberapa pandangannya yaitu meraih mutu merupakan proses yang tidak kenal akhir; perbaikan mutu merupakan proses yang berkesinambungan; mutu memerlukan kepemimpinan dari anggota dewan sekolah dan administratif; prasyarat mutu adalah adanya pelatihan seluruh warga sekolah (Nurzazin, 2011:55). Dengan demikian, mutu dapat diartikan sebagai segala sesuatu yang dapat diperbaiki karena pada dasarnya tidak ada yang sempurna. Mutu juga dapat diartikan sebagai sesuatu yang bisa memenuhi standar dan sesuai dengan tujuan.

Mutu pendidikan secara multidimensi meliputi aspek mutu input, proses, dan output. Oleh karenanya, pengembangan pencapaian mutu harus secara holistik dimulai dari input, proses, dan output. Dalam hal proses pembelajaran sebagai kegiatan inti pendidikan, hasil analisis yang tertuang dalam Rencana Strategis Depdiknas menunjukkan bahwa proses pembelajaran selama ini masih terlalu 
berorientasi terhadap penguasaan teori dan hafalan dalam semua bidang studi yang menyebabkan kemampuan belajar peserta didik menjadi terhambat, metode pembelajaran yang terlalu berorientasi pada guru cenderung mengabaikan hak-hak dan kebutuhan serta pertumbuhan dan perkembangan peserta didik, sehingga proses pembelajaran yang menyenangkan, mengasyikkan, dan mencerdaskan menjadi kurang optimal, muatan belajar juga terlalu terstruktur dan sarat beban juga mengakibatkan proses pembelajaran di sekolah menjadi steril dengan keadaan dan perubahan lingkungan fisik dan sosial di lingkungan Depdiknas, 2006). Keadaan ini menjadikan proses belajar menjadi rutin, kurang menarik, dan kurang mampu memupuk kreativitas sehingga mempengaruhi efisiensi pendidikan, angka mengulang kelas dan putus sekolah.

Dalam Peraturan Pemerintah Nomor 19 tahun 2005 tentang Standar Nasional Pendidikan salah satu standar yang harus dikembangkan adalah standar proses. Standar inilah yang dapat dijadikan sebagai alat untuk mengukur kualitas pendidikan pada umumnya dan kualitas pembelajaran pada khususnya adalah standar proses. Standar proses adalah standar nasional pendidikan yang berkaitan dengan pelaksanaan pembelajaran pada satuan pendidikan untuk mencapai kompetensi lulusan. Dari pengertian di atas, ada tiga hal penting yang perlu dijelaskan. Pertama, standar proses adalah standar nasional pendidikan, artinya standar proses ini berlaku untuk jenjang pendidikan dasar dan menengah pada jalur formal, baik pada sistem paket maupun pada sistem kredit semester. Kedua, Standar proses pendidikan berkaitan dengan pelaksanaan pembelajaran, artinya dalam standar proses pendidikan berisi bagaimana seharusnya proses pembelajaran berlangsung. Ketiga, standar proses pendidikan diarahkan untuk mencapai standar kompetensi lulusan. Artinya standar kompetensi lulusan merupakan rujukan dalam menentukan standar proses pendidikan, karena itu standar proses pendidikan dirumuskan dan ditetapkan tatkala telah tersusun standar kompetensi lulusan (Ardani, 2010).
Dengan demikian, untuk mengetahui pembelajaran yang bermutu maka perlu dikaji mutu dari segi proses. Dari segi proses, mutu pembelajaran berarti keefektifan dan efisiensi seluruh faktor yang berperan dalam proses pendidikan. Kualitas pembelajaran artinya bagaimana kegiatan pembelajaran yang dilakukan selama ini berjalan dengan baik serta menghasilkan luaran yang baik pula. Agar pelaksanaan pembelajaran berjalan dengan baik dan hasilnya dapat diandalkan maka perbaikan pembelajaran diarahkan pada pengelolaan proses pembelajaran (Uno, 2008:153). Dengan demikian, proses pembelajaran harus dimaksimalkan agar dapat meningkatkan pembelajaran yang berkualitas.

Salah satu kegiatan dalam proses pembelajaran adalah penilaian pembelajaran. Penilaian proses pembelajaran adalah partisipasi guru dan peserta didik, interaksi, suasana pembelajaran, mutu pembelajaran dan komponen pembelajaran lainnya. Menurut Muslich dalam Abdul Majid (2015:156), penilaian proses kegiatan pembelajaran dapat dilakukan dengan berbagai cara yaitu menggunakan lembar observasi baik untuk menilai peserta didik, guru, maupun untuk menilai keduanya dan menilai interaksi yang terjadi di dalam kelas, selama pembelajaran itu berlangsung.

\section{METODE PENELITIAN}

Penelitian ini adalah penelitian lapangan atau field research. Jenis penelitiannya adalah penelitian deskriptif kualitatif. Penelitian deskriptif kualitatif yaitu penelitian yang bertujuan menganalisis dan menyajikan fakta secara sistematik tentang keadaan obyek yang diteliti dengan menghasilkan data deskriptif berupa kata-kata tertulis dan lisan dari perilaku yang diamati. Pendekatan yang digunakan adalah pendekatan psikologis dan pedagogis. instrumen yang digunakan dalam penelitian ini yaitu pedoman wawancara, pedoman observasi dan dokumen. Sumber data dalam penelitian ini adalah kepala madrasah, guru kelas, dan peserta didik pada Madrasah Ibtidaiah di Watampone. Teknik pengumpulan data melalui observasi, wawancara dan dokumentasi dan analisis data 
dengan cara kualitatif bersifat induktif yaitu suatu analisis berdasarkan data yang diperoleh, selanjutnya dikembangkan menjadi jawaban terhadap permasalahan dalam penelitian ini. Analisis dalam penelitian ini lebih difokuskan selama proses di lapangan bersamaan dengan pengumpulan data melalui aktivitas reduksi data, penyajian data, penarikan kesimpulan dan verifikasi.

\section{PEMBAHASAN}

Bentuk-bentuk Penerapan Penilaian Autentik Pada Pembelajaran Berbasis Tematik bagi Guru Madrasah Ibtidaiah di Watampone

Penilaian autentik pada pembelajaran berbasis tematik di Madrasah Ibtidaiah Watampone telah dilaksanakan sesuai Kurikulum 2013 SD/MI, walaupun berbagai teknik penilaian belum maksimal dilakukan, akan tetapi telah diterapkan dengan baik oleh guru pada Madrasah Ibtidaiah di Watampone. Pelaksanaan penilaiannya dalam pembelajaran berbasis aktivitas yaitu menilai berbagai aktivitas yang dilakukan peserta didik pada Madrasah Ibtidaiah di Watampone sehingga menghasilkan peserta didik yang kreatif, inovatif, dan berkarakter melalui penguatan sikap, pengetahuan dan keterampilan yang dilakukan secara integratif. Beberapa bentuk penerapan penilaian autentik yang dilakukan oleh guru pada Madrasah Ibtidaiah di Watampone :

\section{Penilaian kompetensi sikap}

Penilaian ini diterapkan agar peserta didik memiliki perilaku yang baik. Perilakunya diobservasi baik harian ataupun dibuatkan jurnal. Observasi dan jurnal dibuat untuk mengetahui perilaku yang menonjol, sangat baik atau perlu bimbingan yang dilihat selama proses pembelajaran dan di luar proses pembelajaran. Jika tidak ada catatan perlu diberi bimbingan maka peserta didik dikategorikan sebagai peserta didik yang memiliki pribadi yang baik. Adapun teknik penilaian kompetensi sikap tergambar pada tabel berikut ini :

\begin{tabular}{|c|c|c|}
\hline \multirow{8}{*}{$\begin{array}{l}\text { Penilaian } \\
\text { Kompetensi } \\
\text { Sikap }\end{array}$} & $\begin{array}{l}\text { Observasi } \\
\text { Harian }\end{array}$ & $\begin{array}{l}\text { Mengamati sikap atau } \\
\text { perilaku peserta didik } \\
\text { yang menonjol dan } \\
\text { pemberian bimbingan }\end{array}$ \\
\hline & Jurnal & $\begin{array}{l}\text { Catatan perilaku peserta } \\
\text { didik dan tindak } \\
\text { lanjutnya }\end{array}$ \\
\hline & Penilaian & Penilaian \\
\hline & Diri & $\begin{array}{l}\text { Menggunakan Model } \\
\text { "Ya" dan "Tidak" }\end{array}$ \\
\hline & Penilaian & Penilaian Antar Peserta \\
\hline & Antar & Didik Menggunakan \\
\hline & Peserta & Model "Ya" dan \\
\hline & Didik & "Tidak" \\
\hline
\end{tabular}

\section{Penilaian Kompetensi Pengetahuan}

Penilaian kompetensi pengetahuan merupakan penilaian yang dilakukan oleh guru Madrasah Ibtidaiah di Watampone untuk mengukur penguasaan pengetahuan dan ketuntasan belajar peserta didik, serta mengetahui kelemahan dan keunggulannya dalam proses pembelajaran. Penilaian pengetahuan dilakukan dengan teknik pemberian tes secara tertulis, lisan dan pemberian tugas.

Pada umumnya, guru Madrasah Ibtidaiah di Watampone lebih banyak memberikan tes tertulis. Tes lisan hanya berlangsung pada saat proses pembelajaran ketika guru Madrasah Ibtidaiah di Watampone melakukan tanya jawab kepada peserta didik atau di akhir pembelajaran ketika akan menutup pembelajaran. Selain itu, guru Madrasah Ibtidaiah di Watampone juga menggunakan penugasan untuk menilai pengetahuan peserta didik. Adapun teknik penilaian kompetensi pengetahuan tergambar pada skema berikut ini :

\begin{tabular}{|c|c|c|}
\hline \multirow[t]{3}{*}{$\begin{array}{l}\text { Penilaian } \\
\text { Pengetahuan }\end{array}$} & Tes Tertulis & $\begin{array}{l}\text { Mengukur capaian } \\
\text { pembelajaran dengan } \\
\text { memberikan tes tertulis } \\
\text { berupa pilihan ganda, } \\
\text { menjodohkan, } \\
\text { melengkapi/isian dan } \\
\text { menjelaskan/uraian }\end{array}$ \\
\hline & Tes Lisan & $\begin{array}{l}\text { Tanya jawab dalam proses } \\
\text { pembelajaran }\end{array}$ \\
\hline & Penugasan & $\begin{array}{l}\text { Tugas diberikan secara } \\
\text { individual dan kelompok } \\
\text { baik di kelas, di luar sekolah } \\
\text { maupun di rumah }\end{array}$ \\
\hline
\end{tabular}

Hasil Observasi dan Wawancara tentang Penilaian Kompetensi Sikap 


\section{Penilaian Kompetensi Keterampilan}

Adapun analisis penilaian kompetensi keterampilan dalam penilaian autentik bagi Guru Madrasah Ibtidaiah di Watampone berdasarkan hasil observasi dan wawancara dapat dilihat tabel berikut ini :

Penilaian Kompetensi Keterampilan dalam Penilaian Autentik

\begin{tabular}{|c|c|c|}
\hline Praktik & $\begin{array}{lr}\text { Kemampuan } & \text { peserta } \\
\text { didik } & \text { dalam } \\
\text { melakukan } & \text { suatu } \\
\text { kegiatan } & \\
\end{array}$ & $\begin{array}{lr}\text { Praktik } & \text { persiapan } \\
\text { membaca permulaan, } \\
\text { praktik membaca } \\
\text { cepat, dan seterusnya. }\end{array}$ \\
\hline Proyek & $\begin{array}{l}\text { Kemampuan peserta } \\
\text { didik dalam } \\
\text { menyelesaikan tugas } \\
\text { yang diberikan pada } \\
\text { periode tertentu }\end{array}$ & $\begin{array}{l}\text { Menyelesaikan tugas } \\
\text { dalam membuat tempat } \\
\text { tisu, membuat silsilah } \\
\text { keluarga, dst. }\end{array}$ \\
\hline Produk & $\begin{array}{l}\text { Kemampuan peserta } \\
\text { didik dalam } \\
\text { pencapaian } \\
\text { pembelajaran yang } \\
\text { menghasilkan } \\
\text { sesuatu/hasil karya }\end{array}$ & $\begin{array}{l}\text { Membuat hasil karya } \\
\text { berupa gambar, pot } \\
\text { bunga, kolase, dan } \\
\text { lain-lain }\end{array}$ \\
\hline Portofolio & $\begin{array}{l}\text { Rekaman penilaian } \\
\text { perkembangan atau } \\
\text { kemajuan dan } \\
\text { kualitas tugas yang } \\
\text { diberikan kepada } \\
\text { peserta didik }\end{array}$ & $\begin{array}{l}\text { Kumpulan hasil kerja } \\
\text { peserta didik berupa } \\
\text { memasangkan gambar }\end{array}$ \\
\hline
\end{tabular}

Demikian penilaian autentik yang diterapkan oleh guru Madrasah Ibtidaiah di Watampone. Penilaian autentiknya dilakukan semaksimal mungkin sesuai dengan kemampuan sekolah terutama kemampuan atau penguasaan gurunya dalam memahami penilaian autentik. Perlu ditegaskan bahwa pada umumnya guru Madrasah Ibtidaiah telah melakukan penilaian autentik walaupun belum optimal karena masih ada teknik penilaian yang jarang dilakukan oleh guru Madrasah Ibtidaiah di Watampone terutama pada tes lisan dan tes praktik. Tes lisan hanya dilakukan pada saat proses pembelajaran, dan tidak dilakukan pada tes hasil pembelajaran. Sedangkan tes praktik dilakukan dengan menyesuaikan materi atau mata pelajarannya.

\section{Kualitas Proses Pembelajaran Guru Madrasah Ibtidaiah di Watampone}

Pada Madrasah Ibtidaiah di Watampone, guru berupaya meningkatkan kualitas proses pembelajaran dimulai dari aspek perencanaan, pelaksanaan, penilaian atau hasil dan pengawasan proses pembelajaran. Pada aspek perencanaan proses pembelajaran, guru Madrasah Ibtidaiah di Watampone merancang pembelajaran dengan baik dan membuat rencana pelaksanaan pembelajaran (RPP) sesuai dengan kurikulum 2013. Pada aspek pelaksanaan proses pembelajaran, guru Madrasah Ibtidaiah di Watampone sebelum melaksanakan pembelajaran telah memenuhi persyaratan pelaksanaan proses pembelajaran dengan menentukan alokasi waktu tatap muka pembelajaran tematik, menggunakan buku tematik, dan mengelola kelas dengan baik, serta dalam melaksanakan pembelajaran telah melakukan langkah-langkah pembelajaran yang dimulai dengan kegiatan pendahuluan, kegiatan inti pembelajaran dengan memaparkan dan menguasai materi melalui penggunaan model pembelajaran yang tepat, metode pembelajaran, media dan sumber belajar yang telah disesuaikan dengan karakteristik peserta didik dan materi pembelajaran. Sedangkan, pada kegiatan penutup, guru Madrasah Ibtidaiah di Watampone melakukan refleksi dan umpan balik untuk mengevaluasi aktivitas proses pembelajaran.

Dalam aspek penilaian proses dan hasil pembelajaran, guru Madrasah Ibtidaiah di Watampone telah menggunakan pendekatan autentik dengan mengarah pada tiga kompetensi penilaian baik sikap, pengetahuan dan keterampilan dengan memberikan penilaian harian, penilaian tengah semester, penilaian akhir, pengayaan dan remedial, rekap nilai, dan penulisan rapor. Penilaian harian merupakan rata-rata nilai dari penilaian harian baik tes dan non tes pada setiap kompetensi dasar permuatan pelajaran/mata pelajaran. Penilaian tengah semester nilai setiap kompetensi dasar pengetahuan per-muatan pelajaran/mata pelajaran. Sedangkan nilai akhir semester merupakan penilaian akhir tahun setiap kompetensi dasar pengetahuan per-muatan pelajaran/mata pelajaran. Adapun analisis rincian penilaian proses pembelajaran bagi guru Madrasah Ibtidaiah di Watampone yaitu : 
Penilaian Proses Pembelajaran Guru Madrasah Ibtidaiah di Watampone:

\begin{tabular}{|c|c|c|}
\hline $\begin{array}{l}\text { Penilaian } \\
\text { Kompetensi } \\
\text { Sikap }\end{array}$ & $\begin{array}{lr}\text { Sikap } & \text { Spiritual } \\
(\text { KI-1) } & \\
\text { Sikap } & \text { Sosial } \\
(\text { KI-2) } & \end{array}$ & $\begin{array}{l}\text { Observasi Harian, } \\
\text { Jurnal Harian, Rekap } \\
\text { Jurnal Semester, Rapat } \\
\text { Dewan Guru, Rapor } \\
\text { Deskripsi Sikap }\end{array}$ \\
\hline $\begin{array}{l}\text { Penilaian } \\
\text { Kompetensi } \\
\text { Pengetahuan }\end{array}$ & $\begin{array}{l}\text { Penilaian } \\
\text { Harian, } \\
\text { Penilaian } \\
\text { Tengah } \\
\text { Semester, dan } \\
\text { Penilaian Akhir } \\
\text { Semester }\end{array}$ & $\begin{array}{l}\text { Ujian harian pertema, } \\
\text { membuat kisi-kisi, } \\
\text { soal, pelaksanaan, } \\
\text { analisis penilaian, } \\
\text { remedi, pengayaan, } \\
\text { rekap nilai rapor dan } \\
\text { deskripsi nilai } \\
\text { pengetahuan }\end{array}$ \\
\hline $\begin{array}{l}\text { Penilaian } \\
\text { Kompetensi } \\
\text { Keterampilan }\end{array}$ & $\begin{array}{l}\text { Praktek, } \\
\text { Produk, } \\
\text { Portofolio } \\
\text { Proyek }\end{array}$ & $\begin{array}{l}\text { Membuat Instrumen } \\
\text { dan menentukan nilai } \\
\text { dan deskripsi }\end{array}$ \\
\hline
\end{tabular}

Pada aspek pengawasan proses pembelajaran, guru Madrasah Ibtidaiah di Watampone telah dipantau dengan cara melakukan diskusi, wawancara, pengamatan dan dokumentasi dalam proses pembelajaran, dilakukan supervisi oleh kepala madrasah dan supervisor, dibuatkan laporan dan diberi tindak lanjut oleh kepala madrasah dan pengawas dengan memberikan kesempatan kepada guru Madrasah ibtidaiah di Watampone untuk mengikuti program peningkatan dan pengembangan kompetensi profesional demi meningkatkan kualitas proses pembelajaran. Dengan demikian, berdasarkan hasil temuan dari peneliti dapat dikatakan bahwa guru dan pihak madrasah telah berupaya meningkatkan kualitas proses pembelajaran dan telah menerapkan sesuai dimensi kualitas proses pembelajaran. Penilaian proses telah dilakukan oleh guru Madrasah Ibtidaiah di Watampone sesuai dimensi kualitas penilaian proses pembelajaran

\begin{tabular}{|c|c|}
\hline $\begin{array}{l}\text { Kemampuan } \\
\text { Guru } \\
\text { dalam } \\
\text { Penguasaan } \\
\text { Penilaian } \\
\text { Autentik } \\
\end{array}$ & $\begin{array}{l}\text { Guru memiliki kemampuan yang } \\
\text { berbeda-beda tergantung dari seberapa } \\
\text { besar upaya atau usaha mereka dalam } \\
\text { memahami penilaian autentik dan } \\
\text { menerapkannya dalam pembelajaran }\end{array}$ \\
\hline $\begin{array}{l}\text { Terbatasnya } \\
\text { Waktu }\end{array}$ & $\begin{array}{l}\text { Dalam menerapkan penilaian autentik } \\
\text { pada pembelajaran tematik, } \\
\text { memerlukan waktu yang cukup banyak } \\
\text { karena banyak penilaian yang harus } \\
\text { dinilai oleh guru dimulai dari penilaian } \\
\text { sikap, pengetahuan dan keterampilan }\end{array}$ \\
\hline $\begin{array}{l}\text { Ribet dan Tidak } \\
\text { Praktis }\end{array}$ & $\begin{array}{l}\text { Terlalu banyak rubrik penilaiannya } \\
\text { sehingga merepotkan bagi guru dalam } \\
\text { melakukan penilaian dan } \\
\text { memungkinkan guru tidak maksimal } \\
\text { dalam melakukan penilaian }\end{array}$ \\
\hline
\end{tabular}

sebagaimana tertuang dalam Permendikbud No. 65 Tahun 2013.

Faktor Pendukung dan Penghambat Guru Madrasah Ibtidaiah di Watampone dalam Menerapkan Penilaian Autentik Pada Pembelajaran Berbasis Tematik untuk Meningkatkan Kualitas Penilaian Proses Pembelajaran

Ada beberapa faktor yang menjadi pendukung dan penghambat atau menjadi kendala guru Madrasah Ibtidaiah di Watampone dalam menerapkan penilaian autentik pada pembelajaran tematik untuk meningkatkan kualitas penilaian proses pembelajaran terlihat pada tabel berikut ini :

Faktor Pendukung Guru Madrasah Ibtidaiyah dalam Menerapkan Penilaian Autentik

\begin{tabular}{|c|c|}
\hline Pelatihan & $\begin{array}{lrr}\text { Guru diberi } & \text { kesempatan untuk } \\
\text { meningkatkan } & \text { kompetensi } \\
\text { profesionalnya } & \text { melalui pelatihan } \\
\text { khususnya pelatihan } & \text { dalam } \\
\text { melakukan penilaian autentik sesuai } \\
\text { dengan kurikulum } 2013 \text { yang } \\
\text { dilaksanakan oleh pihak Madrasah } \\
\text { Ibtidaiyah, KKG (Kelompok Kerja } \\
\text { Guru), dan Kementerian Agama } \\
\text { Kab.Bone }\end{array}$ \\
\hline $\begin{array}{lr}\text { Buku Panduan } \\
\text { Penilaian }\end{array}$ & $\begin{array}{l}\text { Guru diberi panduan dalam } \\
\text { melakukan penilaian autentik } \\
\text { sehingga guru tidak hanya menilai } \\
\text { pengetahuan dan keterampilan tetapi } \\
\text { juga menilai sikap }\end{array}$ \\
\hline Pendampingan & $\begin{array}{l}\text { Guru diberi pendampingan dalam } \\
\text { melaksanakan penilaian autentik baik } \\
\text { pendampingan dari mulai dari kepala } \\
\text { madrasah, pengawas, KKG, dan } \\
\text { teman sejawat }\end{array}$ \\
\hline
\end{tabular}

Faktor Penghambat atau Kendala yang Dihadapi Guru Madrasah Ibtidaiah di Watampone dalam Menerapkan Penilaian Autentik

\begin{tabular}{|c|c|}
\hline $\begin{array}{l}\text { Kemampuan } \\
\text { Guru } \\
\text { dalam } \\
\text { Penguasaan } \\
\text { Penilaian } \\
\text { Autentik } \\
\end{array}$ & $\begin{array}{l}\text { Guru memiliki kemampuan yang } \\
\text { berbeda-beda tergantung dari seberapa } \\
\text { besar upaya atau usaha mereka dalam } \\
\text { memahami penilaian autentik dan } \\
\text { menerapkannya dalam pembelajaran }\end{array}$ \\
\hline $\begin{array}{l}\text { Terbatasnya } \\
\text { Waktu }\end{array}$ & $\begin{array}{l}\text { Dalam menerapkan penilaian autentik } \\
\text { pada pembelajaran tematik, } \\
\text { memerlukan waktu yang cukup banyak } \\
\text { karena banyak penilaian yang harus } \\
\text { dinilai oleh guru dimulai dari penilaian } \\
\text { sikap, pengetahuan dan keterampilan }\end{array}$ \\
\hline $\begin{array}{l}\text { Ribet dan Tidak } \\
\text { Praktis }\end{array}$ & $\begin{array}{l}\text { Terlalu banyak rubrik penilaiannya } \\
\text { sehingga merepotkan bagi guru dalam } \\
\text { melakukan penilaian dan } \\
\text { memungkinkan guru tidak maksimal } \\
\text { dalam melakukan penilaian }\end{array}$ \\
\hline
\end{tabular}


Berbagai penghambat atau kendala yang dihadapi oleh guru Madrasah Ibtidaiah di Watampone telah diatasi oleh pihak Madrasah Ibtidaiah di Watampone dengan berbagai cara melalui pelatihan dan keaktifan guru dalam organisasi keguruan yang dapat meningkatkan kompetensinya baik kompetensi profesional maupun kompetensi lainnya.

\section{PENUTUP}

Pada umumnya guru Madrasah Ibtidaiah di Watampone telah menerapkan penilaian autentik pada pembelajaran berbasis tematik dalam meningkatkan kualitas penilaian proses pembelajaran walaupun belum optimal. Bentuk penerapannya adalah menilai kompetensi sikap, pengetahuan dan keterampilan peserta didik pada Madrasah Ibtidaiah di Watampone. Penilaian kompetensi sikap melalui teknik observasi, penilaian diri, penilaian teman sejawat oleh peserta didik, dan jurnal. Penilaian kompetensi pengetahuan lebih banyak menggunakan tes tertulis, dari pada tes lisan, serta pemberian tugas. Penilaian kompetensi keterampilan melalui tes praktik, proyek, dan portofolio. Guru Madrasah Ibtidaiah di Watampone telah berupaya meningkatkan kualitas proses pembelajaran melalui perencanaan, pelaksanaan, penilaian dan hasil pembelajaran, serta Kepala Madrasah Ibtidaiah di Watampone dan supervisor telah melakukan pengawasan proses pembelajaran dan telah sesuai dengan standar kualitas proses pembelajaran. Selanjutnya, ada beberapa faktor pendukung bagi guru Madrasah Ibtidaiah di Watampone dalam menerapkan penilaian autentik yaitu diberikan pelatihan, buku panduan penilaian autentik, dan pendampingan. Selain faktor pendukung, guru Madrasah Ibtidaiah di Watampone juga mengalami hambatan dalam menerapkan penilaian autentik dalam meningkatkan kualitas proses pembelajaran yaitu kemampuan guru Madrasah Ibtidaiah di Watampone yang berbeda-beda, terbatasnya waktu, ribet dan tidak praktis dalam menerapkannya.

\section{UCAPAN TERIMA KASIH}

Penulis mengaturkan banyak terima kasih kepada semua pihak yang ikut berkontribusi pada penelitian yang akhirnya melahirkan artikel ini, terutama pada kalangan responden yaitu kepala madrasah, guru kelas, dan peserta didik pada Madrasah Ibtidaiah di Watampone, dan tak lupa pula penulis ucapkan terima kasih kepada pihak pengelola jurnal AlQalam yang telah memasukkan artikel ini sebagai bagian edisi ini.

\section{DAFTAR PUSTAKA}

Ardani, et.al., Pengendali Mutu Pembelajaran. Elyakimstar.blogspot. com./2011/01/ pengendali-mutu-pembelajaran.html?m1. Makalah Manajemen Kendali Mutu Pembelajaran, Program Pascasarjana Program Studi Manajemen Pendidikan, Universitas Sarjanawiyata Tamansiswa, Yogyakarta, 2010. Diunduh pada tanggal 17 November 2018.

Arifin, Zainal. Evaluasi Pembelajaran: Prinsip, Teknik, Prosedur. Bandung: Remaja Rosdakarya, 2009.

Daryanto dan Karim, Syaiful. Pembelajaran Abad 21. Cet. I; Yogyakarta: Gava Media, 2017.

Depdiknas, Rencana Strategis Departemen Pendidikan Nasional. Jakarta: 2006

Kunandar. Penilaian Autentik : Penilaian Hasil Belajar Peserta Didik Berdasarkan Kurikulum 2013. Cet. III; Jakarta: Rajawali Pers, 2014.

Majid, Abdul. Penilaian Autentik Proses dan Hasil Belajar. Cet. II; Bandung: Remaja Rosdakarya, 2015.

Nurzazin. Gerakan Menata Mutu Pendidikan: Teori dan Aplikasi. Cet. I; Jogyakarta: ArRuzz Media, 2011.

Pantiwati, Yuni. Hakekat Asesmen Autentik dan Penerapannya dalam Pembelajaran Biologi dalam Jurnal Edukasi Matematika dan Sains Vol. 1 No.1, diakses pada tanggal 23 April 2018.

Peraturan Menteri Pendidikan dan Kebudayaan No. 65 Tahun 2013 tentang Standar Proses Pendidikan Dasar dan Menengah. 
Permendikbud RI No. 66 Tahun 2013 tentang Standar Penilaian Pendidikan.

Sani, Ridwan Abdullah. Penilaian Autentik. Cet. I; Jakarta: Bumi Aksara, 2016.

Supardi. Penilaian Autentik: Pembelajaran Afektif, Kognitif dan Psikomotorik : Konsep dan Aplikasi. Cet. I; Jakarta: Rajawali Pers, 2015.
Uno, Hamzah B. Model Pembelajaran: Menciptakan Proses Belajar Mengajar yang Kreatif dan Efektif. Cet. III; Jakarta: Bumi Aksara, 2008.

Widoyoko, S. Eko Putro. Evaluasi Program Pembelajaran: Panduan Praktis Bagi Guru dan Calon Pendidik. Cet. IX; Yogyakarta: Pustaka Pelajar, 2017. 